\title{
Genetic Parameters in Seed Yield Components of Cowpea (Vigna unguiculata (L.) Walp.)
}

\author{
N. Thouseem*, Beena Thomas and Namitha Elizabeth \\ College of Agriculture, Vellayani, Trivandrum- 695522, India \\ *Corresponding author
}

\section{A B S T R A C T}

Keywords

Cowpea, Genetic parameters,

Heritability,

Genetic advance

Article Info

Accepted:

20 January 2018

Available Online:

10 February 2018
The phenotypic coefficient of variation was found to be higher than the genotypic coefficient of variation for all the traits studied. The highest magnitude of GCV was observed for pod weight followed by number of pod clusters plant ${ }^{-1}$, seed yield plant ${ }^{-1}, 100$ seed weight, pod length, number of pods cluster ${ }^{-1}$ and number of pods plant ${ }^{-1}$. All the characters considered except number of primary branches plant ${ }^{-1}$, number of pods plant ${ }^{-1}$ and seed yield plant $^{-1}$ recorded high estimates of heritability. High heritability coupled with high genetic advance was observed for days to 50 per cent flowering, length of main stem, number of pod clusters plant ${ }^{-1}$, number of pods cluster ${ }^{-1}$, pod weight, pod length, pod girth, number of seeds pod $^{-1}$, and 100 seed weight.

\section{Introduction}

Cowpea [Vigna unguiculata (L.) Walp] also known black-eyed pea, southern pea etc is a pulse crop rich in proteins, vitamins and minerals and is mainly grown for grain, vegetable and fodder purposes. Low productivity is one of the major constrain in pulse production. Considerable research regarding selection criteria for yield is very essential to increase the productivity of pulses to meet the increasing demands of growing population. Greater the genetic variability, greater the chances for the selection of better genotypes. The genetic parameters like genotypic coefficient of variation (GCV) and phenotypic coefficient of variation (PCV) gives an idea about magnitude of variability present in a genetic population. The estimates of genetic parameters like heritability and genetic advance help the plant breeder in selection of elite genotypes from diverse genetic populations. Therefore plant breeding efforts should aim at the manipulation of available genetic diversity in the desired direction through suitable selection criteria. Keeping these aspects in view, the present investigation was undertaken to study genetic variability, heritability, and genetic advance in cowpea genotypes. 


\section{Materials and Methods}

The experimental crop was raised during the period of April 2016 to July 2016 in a farmer field Kayamkulam in randomized block design with three replication. The experimental field was divided into three blocks of thirty plots each and the treatment was allotted to each block at random. The plot size was $3 \mathrm{~m}^{2}$. Spacing was $30 \mathrm{~cm}$ between rows and $10 \mathrm{~cm}$ between plants in a row. The genotypes were evaluated for following traits viz., days to 50 percent flowering, number of primary branches plant ${ }^{-1}$, length of main stem $(\mathrm{cm})$, number of pod clusters plant ${ }^{-1}$, number of pods cluster ${ }^{-1}$, number of pods plant ${ }^{-1}$, pod weight $(\mathrm{g})$, pod length $(\mathrm{cm})$, pod girth $(\mathrm{mm})$, number of seeds pod $^{-1}, 100$ seed weight $(\mathrm{g})$, seed yield plant ${ }^{-1}(\mathrm{~g})$ and crop duration (days).

The data studied on various parameters were subjected to statistical analysis as per methods suggested by Panse and Sukhatme (1967) for analysis of variance, Burton (1952) for variability, Lush (1940) for heritability (Broad Sense) and Johnson et al., (1955) for genetic advance in per cent of mean.

\section{Results and Discussion}

\section{Genetic parameters}

The various genetic parameters like GCV, PCV, heritability and genetic advance were calculated for different characters for all the thirty genotypes and recorded in the table 1 . PCV was greater than GCV for all the characters studied.

\section{Genotypic coefficient of variation (GCV)}

Genotypic coefficient of variation (GCV) ranged from 10.33 (crop duration) to 47.73 (pod weight). Highest GCV was observed for pod weight (47.73) followed by number of pod clusters plant ${ }^{-1}$ (24.99), seed yield plant ${ }^{-1}$
(24.43), 100 seed weight (24.07), pod length (23.66), number of pods cluster $^{-1}$ (20.86) and number of pods plant ${ }^{-1}$ (20.66). Number of primary branches plant ${ }^{-1}$ (19.46), pod girth (18.75), length of main stem (16.22), days to 50 per cent flowering (15.28), number of seeds $\operatorname{pod}^{-1}$ (12.37) and crop duration (11.67) exhibited moderate level of GCV. None of the characters exhibited low magnitude of GCV.

\section{Phenotypic coefficient of variation}

The phenotypic coefficient of variation (PCV) ranged from 11.67 (crop duration) to 52.12 (pod weight). Highest PCV was for pod weight (52.12) followed by seed yield plant ${ }^{-1}$ (31.72), number of pod clusters plant ${ }^{-1}$ (31.36), number of pods plant $^{-1}$ (27.21), number of primary branches plant ${ }^{-1}$ (26.92), 100 seed weight (24.13), pod length (23.81) and number of pods cluster ${ }^{-1}$ (21.32). Length of main stem (18.94), pod girth (18.85), days to 50 per cent flowering (16.44) and number of seeds $\operatorname{pod}^{-1}$ (12.84) and crop duration (11.67) exhibited moderate level PCV. None of the characters exhibited low PCV values.

These findings of GCV and PCV values are in close harmony with the result of Manggoel $e t$ al., (2012) for 100-seed weight, grain yield, number of pods plant ${ }^{-1}$ and Thorat et al., (2013) for number of pods plant ${ }^{-1}$, and number of clusters plant ${ }^{-1}$; Vavilapalli et al., (2013) for pod weight and pod length; Ajayi et al., (2014) for number of pods plant ${ }^{-1}$, pod length, pod weight $(\mathrm{g})$, number of seeds $\operatorname{pod}^{-1}$, and 100-seed weight; Selvakumar et al., (2015) for yield plant ${ }^{-1}$, pod length, number of clusters plant $^{-1}$, number of pods clusters ${ }^{-1}$ and 100 grain weight; Khandait et al., (2016) for number of pods plant ${ }^{-1}$, number of pods cluster $^{-1}$, pod weight and pod length; Rajput (2016) number of pod plant ${ }^{-1}$, number of pods cluster $^{-1}$, pod weight and pod length.; and Srinivas et al., (2017) for number of pods plant $^{-1}$ and number of seeds pod ${ }^{-1}$. 
Int.J.Curr.Microbiol.App.Sci (2018) 7(2): 2268-2274

Table.1 Genetic parameters

\begin{tabular}{|c|c|c|c|c|}
\hline \multirow[t]{2}{*}{ Characters } & \multicolumn{2}{|c|}{$\begin{array}{l}\text { Coefficient of } \\
\text { variation }\end{array}$} & \multirow[t]{2}{*}{ Heritability } & \multirow{2}{*}{$\begin{array}{l}\text { Genetic } \\
\text { advance (as \% } \\
\text { of mean) }\end{array}$} \\
\hline & $\mathrm{GCV}$ & $\mathrm{PCV}$ & & \\
\hline Days to $50 \%$ flowering & 15.28 & 16.44 & 86.45 & 29.28 \\
\hline $\begin{array}{l}\text { No. of primary } \\
\text { branches per plant }\end{array}$ & 19.46 & 26.92 & 52.26 & 28.98 \\
\hline $\begin{array}{l}\text { Length of main stem } \\
\text { (cm) }\end{array}$ & 16.22 & 18.94 & 73.34 & 28.62 \\
\hline $\begin{array}{l}\text { No. of pod clusters per } \\
\text { plant }\end{array}$ & 24.99 & 31.36 & 63.5 & 41.02 \\
\hline No. of pods per cluster & 20.86 & 21.32 & 95.73 & 42.04 \\
\hline No. of pods per plant & 20.66 & 27.21 & 57.67 & 32.33 \\
\hline Pod weight (g) & 47.73 & 52.12 & 83.86 & 90.05 \\
\hline Pod length (cm) & 23.66 & 23.81 & 98.74 & 48.44 \\
\hline Pod girth (mm) & 18.75 & 18.85 & 98.94 & 38.43 \\
\hline $\begin{array}{l}\text { Number of seeds per } \\
\text { pod }\end{array}$ & 12.37 & 12.84 & 92.83 & 24.55 \\
\hline 100 seed weight $(\mathrm{g})$ & 24.07 & 24.13 & 99.41 & 49.43 \\
\hline Seed yield per plant (g) & 24.43 & 31.72 & 59.30 & 38.75 \\
\hline Crop duration (days) & 10.33 & 11.67 & 78.31 & 18.83 \\
\hline
\end{tabular}


Phenotypic and genotypic coefficients of variation for thirteen characters in Cowpea

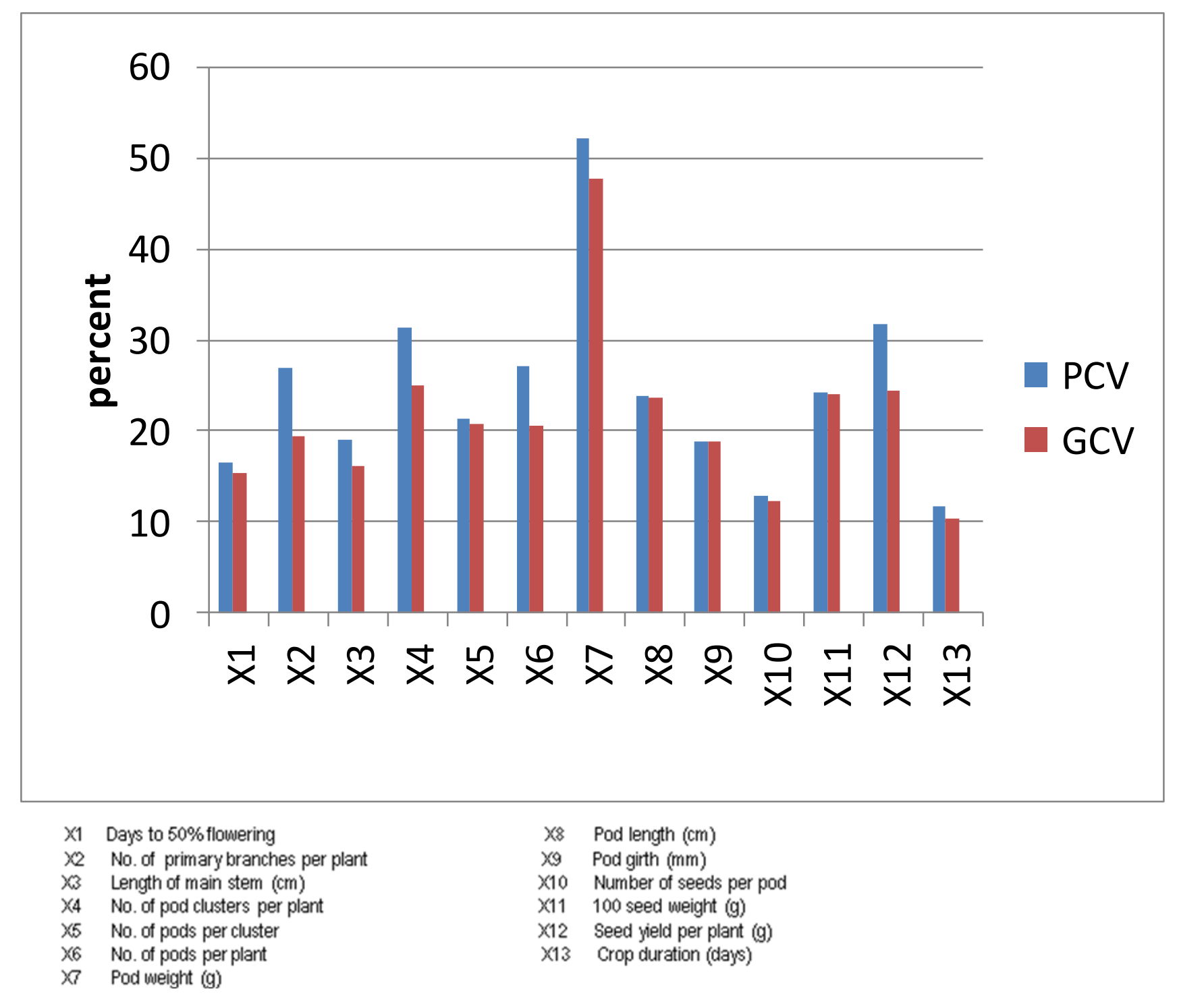


Heritability and Genetic advance for thirteen characters in cowpea

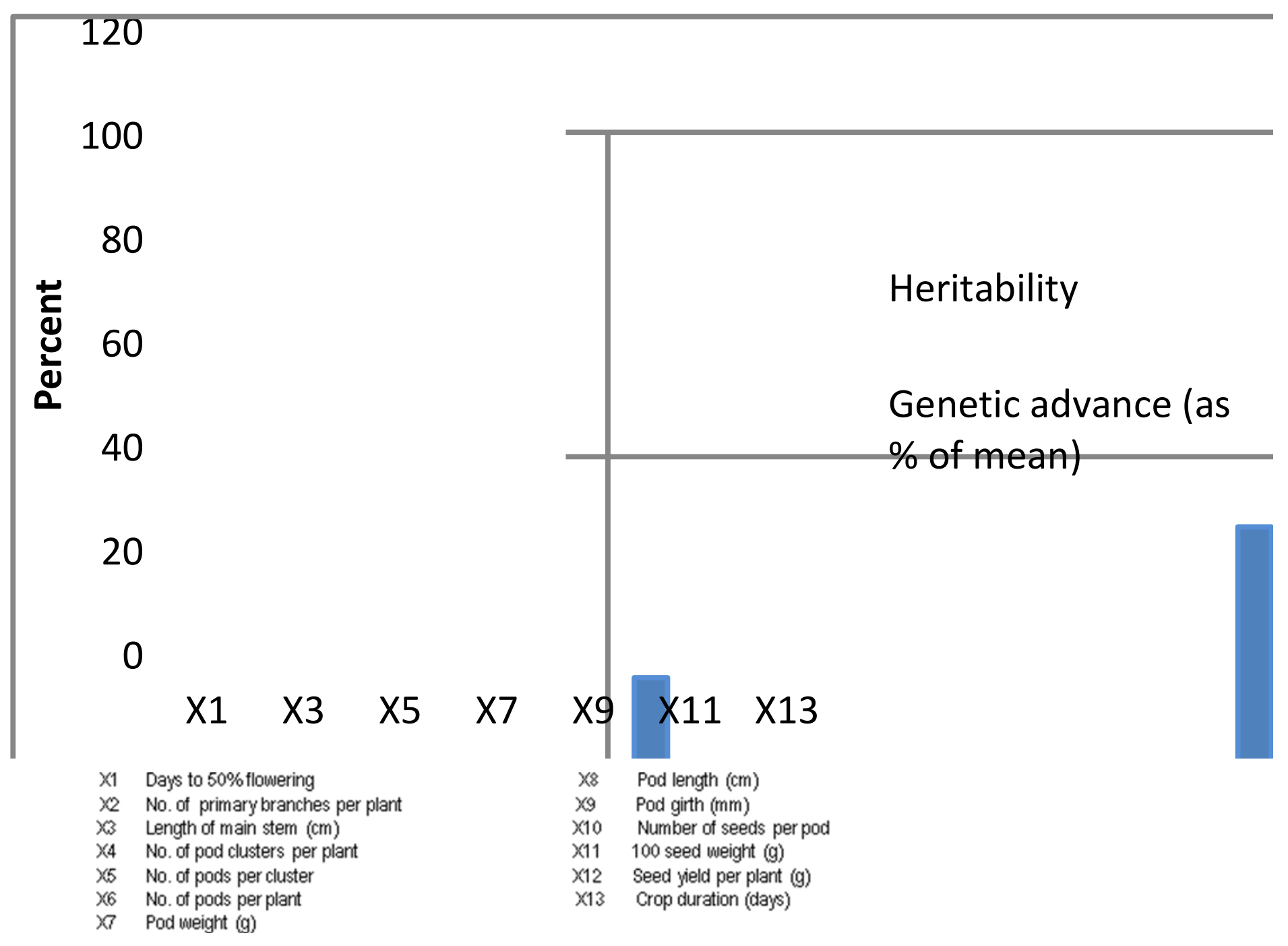


For the characters exhibiting negligible difference between estimates of GCV and PCV, selection will be effective since the environmental influence is low for these characters.

\section{Heritability and Genetic advance}

Heritability (in broad sense) values for the studied traits ranged from $52.26 \%$ to 99.41 $\%$. The highest heritability was obtained for 100 seed weight $(99.41 \%)$ followed by pod girth (98.94 \%), pod length (98.74 \%), number of pods cluster ${ }^{-1}(95.73 \%)$, number of seeds $\operatorname{pod}^{-1}(92.83 \%)$, days to 50 per cent flowering $(86.45 \%)$, pod weight $(83.86 \%)$, crop duration $(78.31 \%)$, length of main stem $(73.34 \%)$ and number of pod clusters plant ${ }^{-1}$ $(63.50 \%)$; while moderate heritability was observed for seed yield plant ${ }^{-1}(59.30 \%)$, number of pods plant ${ }^{-1}(57.67 \%)$ and number of primary branches plant ${ }^{-1}(52.26 \%)$.

Similar findings were recorded Adewale et al., (2010) for seeds pod ${ }^{-1}, 100$ seed weight and pod length; Manggoel et al., (2012) for 100 seed weight, days to 50 per cent flowering, number of seeds $\operatorname{pod}^{-1}$ and pod length; Ajayi et al., (2014) for number of pods plant $^{-1}$, pod length, pod weight $(\mathrm{g})$, number of seeds pod $^{-1}$, and 100-seed weight; Khandait et al., (2016) for pod length and pod weight.

All the characters exhibited high genetic advance (as \% of mean) except crop duration $(18.83 \%)$ which exhibited moderate genetic advance.

The highest estimate was obtained for pod weight $(90.05 \%)$ followed by 100 seed weight (49.43\%), pod length (48.44\%), number of pods cluster ${ }^{-1}(42.04 \%)$, number of pod clusters plant ${ }^{-1}$ (41.02), seed yield plant $^{-1}(38.75 \%)$, pod girth (38.43\%), number of pods plant $^{-1}(32.33 \%)$, days to 50 per cent flowering (29.28\%), number of primary branches plant ${ }^{-1}(28.98 \%)$, length of main stem $(28.62 \%)$ and number of seeds $\operatorname{pod}^{-1}(24.55 \%)$.

Corroborative findings were reported by Suganthi and Murugan (2008) for seed yield plant $^{-1}$, number of pods plant ${ }^{-1}$ and number of clusters plant $^{-1}$; Manggoel et al., (2012) and Khandait et al., (2016) for number of pods plant $^{-1}$, pod length, number of pods cluster ${ }^{-1}$, and pod weight.

High heritability coupled with high genetic advance was observed for days to 50 per cent flowering, length of main stem, number of pod clusters plant ${ }^{-1}$, number of pods cluster ${ }^{-1}$, pod weight, pod length, pod girth, number of seeds pod $^{-1}$, and 100 seed weight. It supports findings of Vavilapalli et al., (2013) for pod length, pod girth and pod weight. Kharde et al., (2014) pod length, average pod weight and number of seeds pod ${ }^{-1}$; Selvakumar et al., (2015) for number of pods clusters ${ }^{-1}$ and 100 grain weight, Srinivas et al., (2017) for number of pods plant ${ }^{-1}$ and number of seeds $\operatorname{pod}^{-1}$.

Heritability estimates along with genetic advance are normally more helpful in predicting the gain under selection than heritability estimates alone (Singh and Chaudhary, 1985).

The pod weight exhibited the highest GCV $(47.73 \%)$ and PCV (52.12\%). Heritability was high for all the characters except number of primary branches plant $^{-1}$, number of pods plant $^{-1}$ and seed yield plant ${ }^{-1}$ which possessed moderate heritability.

GA (\% mean) was high for all the characters except crop duration. High GCV, PCV, Heritability and Genetic advance was found on the characters number of pod clusters ${ }^{-1}$, number of pods cluster ${ }^{-1}$, number of pods plant $^{-1}$, pod weight, pod length and 100 seed weight. Therefore plant breeding efforts 
should aim at the manipulation of available genetic diversity in the desired direction through these selection criteria.

\section{References}

Adewale, B. D., Okonji, C., Oyekanmi, A. A., Akintobi, D. A. C., and Aremu, C. O. 2010.Genotypic variability and stability of some grain yield components of cowpea. Afr. J Agric. Res. 5(9): 874-880.

Ajayi, A. T., Adekola, M. O., Taiwo, B. H., and Azuh, V. O. 2014. Character expression and differences in yield potential of ten genotypes of cowpea (Vigna unguiculata $\mathrm{L}$. Walp). Int. J. Plant Res. 4(3): 63-71.

Burton, G.W. 1952. Proc. 6th Int. Grassl. Cong. 1: 277-283.

Dewey, D. R. and Lu, K. H. 1959. A correlation and path coefficient analysis of components of crested wheat grass seed production. Agron. J. 51: 515-518.

Johnson, H. W., Robinson, H. D., and Comstock, R. E. 1955.Estimates of genetical and environmental variability in soyabeans. Agron. J. 47:314-318.

Khandait, R. Jain, P. K., Singh, Y., Prajapati, S. and Solanki, S. 2016. Genetic Variability in Diverse Genotypes of Cowpea (Vigna unguiculata L.). TECHNOFAME- A J. Multidisciplinary Advance Res. 5(2): 120126.

Kharde, R. P., Kale, V. S. and Bhogave, A. F. 2014. Genetic variability studies in cowpea. Bioinfolet. 11(1 A): 113-118.

Lush, J. L., 1940. Intrasire correlations and regression of offspring on dams as a methods of estimating heritability of characters. Proc. American Society of Animal Production.33: 293-301.

Manggoel, W., Uguru, M. I., Ndam, O. N., and Dasbak, M. A. 2012. Genetic variability, correlation and path coefficient analysis of some yield components of ten cowpea [Vignaunguiculata (L.)Walp] accessions. J. Plant Breed. Crop Sci. 4(5): 80-86.

Panse, V. G. and Sukhatme, P. V. 1967. Statistical Methods for Agricultural Workers. ICAR, New Delhi, pp. 280-297.

Rajput, S. S. 2016. Genetic variability, correlation and path coefficient analysis for yield and its attributing traits in cowpea. M. Sc. (Hort.) thesis. JNKVV, Jabalpur, Madhya Pradesh. 88p.

Selvakumar, G., and Kumari, R. U. 2015. Variability analysis in inter subspecies crosses of cowpea (Vigna unguiculata (L.) Walp). and (Vigna unguiculata (L.) Walp.spp. sesquipedalis). J. Plant Sci. Res. 31(1):109-113.

Singh, R. K., Chaudhary, B. D. 1985. Biometrical Methods in Quantitative Genetics Analysis. Kalyani Publishers, 318 p.

Srinivas, J., Kale, V. S., Nagre, P.K. and Soratur, R. S. 2017. Study of Genetic Variability, Heritability and Genetic Advance in Cowpea [Vigna unguiculata (L.) Walp]. Int. J. Current Microbiol. Appl. Sci. 6(6): 33143318.

Suganthi S and Murugan S. 2008.Association analysis in cowpea [Vigna unguiculata L. Walp.]. Legume Res. 31(2): 130-132.

Thorat, A. and Gadewar, R. D. 2013. Variability and Correlation studies in cowpea (Vigna unguiculata). Int. J. Environ Rehabil. Conserv. 4(1): 44-49.

Vavilapalli, S., Celine, V. A., Duggi, S., Padakipatil, S., and Magadum, S. 2013. Genetic variability and heritability studies in bush cowpea (Vigna unguiculata (L.) Walp.). Legume Genomics Genet. 4(4): 2731.

\section{How to cite this article:}

Thouseem, N., Beena Thomas and Namitha Elizabeth. 2018. Genetic Parameters in Seed Yield Components of Cowpea (Vigna unguiculata (L.) Walp.). Int.J.Curr.Microbiol.App.Sci. 7(02): 2268-2274. doi: https://doi.org/10.20546/ijcmas.2018.702.273 